\title{
SISTEM PENDUKUNG KEPUTUSAN PEMILIHAN MOBIL BEKAS MENGGUNAKAN METODE ANALYTHICAL HIERARCHY PROCESS
}

\author{
Dodi Guswandi ${ }^{1)}$, Gushelmi ${ }^{2}$ \\ ${ }^{1}$ Fakultas Ilmu Komputer, Universitas Putra Indonesia YPTK Padang \\ email: guswandidodi@upiyptk.ac.id \\ ${ }^{2}$ Fakultas Ilmu Komputer, Universitas Putra Indonesia YPTK Padang \\ email: gushelmi@upiyptk.ac.id
}

\begin{abstract}
Showroom Ragasa Motor Padang is a showroom that sells various types of used cars. The old system of selecting used cars in The Ragasa Motor Padang Showroom is that customers come directly to the address of this Showroom and the selection process is still done by manual means. With the development of internet technology today is increasing rapidly and in order to be accessible to everyone, the AHP can do a comparison of the criteria in pairs on the selection of used cars and can determine the consistency of the comparison data paired with a threshold value of $<$ 0.1. The purpose of this research is to make it easier for customers to choose used cars quickly and accurately, as well as the application of programs used to make it easier for customers to use them. The result of this study is the SPK System that was built to be able to take the decision of the selection of used cars in the Showroom Ragasa Motor Padang with the selection of the 2nd alternative with a value of 2.55 as the best choice.
\end{abstract}

Keywords :Showroom, used cars, DSS, AHP

\begin{abstract}
Abstrak
Showroom Ragasa Motor Padang merupakan sebuah Showroom yang menjual berbagai jenis mobil bekas. Sistem yang lama pemilihan mobil bekas pada Showroom Ragasa Motor Padang yaitu pelanggan langsung datang ke alamat Showroom ini dan proses pemilihan masih dilakukan dengan cara manual. Dengan perkembangan teknologi internet saat sekarang ini semakin pesat dan agar dapat diakses oleh semua orang, maka AHP dapat melakukan perbandingan kriteria berpasangan pada pemilihan mobil bekas dan dapat menentukan kekonsistenan data perbandingan berpasangan tersebut dengan nilai Threshold $\leq 0,1$. Tujuan dari penelitian ini adalah memudahkan pelanggan dalam memilih mobil bekas dengan cepat dan akurat, serta aplikasi program yang digunakan memudahkan pelanggan dalam menggunakannya. Hasil dari penelitian ini adalah Sistem SPK yang dibangun mampu mengambil keputusan pemilihan mobil bekas pada Showroom Ragasa Motor Padang dengan terpilihnya alternatif ke-2 dengan nilai 2,55 sebagai pilihan terbaik.
\end{abstract}

Kata Kunci : Showroom, Mobil Bekas, SPK, AHP

\section{PENDAHULUAN}

Perkembangan industri otomotif di Indonesia saat ini semakin berkembang. Hal ini dapat dilihat dari jumlah produksi, jumlah penjualan, hingga jumlah mobil yang beredar di Indonesia semakin meningkat. Berdasarkan survey yang digelar oleh Google dan Netpop alasan terbesar seseorang membeli sebuah mobil adalah untuk mengakomodasi jumlah keluarga yang bertambah besar. Di Indonesia sendiri terdapat banyak merk mobil yang beredar dipasaran. Seperti halnya Showroom Ragasa Motor Padang. Perusahaan ini adalah perusahaan yang bergerak dibidang jasa penjualan mobil bekas di kota Padang. Dalam memenuhi target penjualan yang dilakukan di daerah Padang dan sekitarnya, Showroom 
Ragasa Motor memasarkan mobil bekas hanya melalui iklan surat kabar dan sekedar dengan menyebar brosur diberbagai tempat. Hal tersebut masih belum memenuhi target penjualan yang diinginkan setiap bulannya karena hanya masyarakat kalangan tertentu yang hanya bisa melihat dan melakukan interaksi dalam proses jual beli. Saat ini kebutuhan akan kendaraan di kotakota besar meningkat. Namun, harga kendaraan yang masih terbilang mahal menjadi alasan banyak orang menjadikan mobil bekas sebagai alternatif. Orang-orang sekarang cenderung tidak ambil pusing. Selama kondisi kendaraan masih baik dan bisa digunakan dengan aman, mereka akan mengambilnya [1].

Berdasarkan masalah yang telah ditemukan oleh penulis, maka perlu dibangun sebuah sistem yang baru yang disebut dengan sistem pendukung keputusan. Sistem Pendukung Keputusan adalah suatu sistem informasi spesifik yang ditujukan untuk membantu manajemen dalam mengambil keputusan yang berkaitan dengan persoalan yang bersifat semi terstruktur. Sistem ini memiliki fasilitas untuk menghasilkan berbagai alternatif yang secara interaktif digunakan oleh pemakai [2]. Konsep SPK merupakan sebuah sistem interaktif berbasis komputer yang membantu pembuatan keputusan memanfaatkan data dan model untuk menyelesaikan masalahmasalah yang bersifat tidak terstruktur dan semi terstruktur. SPK dirancang untuk menunjang seluruh tahapan pembuatan keputusan, yang dimulai dari tahapan mengidentifikasi masalah, memilih data yang relevan, menentukan pendekatan yang digunakan dalam proses pembuatan keputusan sampai pada kegiatan mengevaluasi pemilihan alternatif [3].

Ada tiga komponen dasar Decision support system (DSS) [4]: a. Sistem manajemen basis data/database management system (DBMS). DBMS berfungsi sebagai bank data untuk DSS.

b. Model base management system (MBMS). Peran MBMS analog dengan peran DBMS, fungsi utamanya adalah memberikan independendi antara model tertentu yang digunakan dalam DSS dari aplikasi yang menggunakannya.

c. Dialog generation and management system (DGMS). Produk utama dari interaksi dengan DSS adalah wawasan. Karena penggunanya seringkali adalah orang yang tidak terlatih dengan komputer, DSS perlu dilengkapi dengan antarmuka yang intuitif dan mudah digunakan.

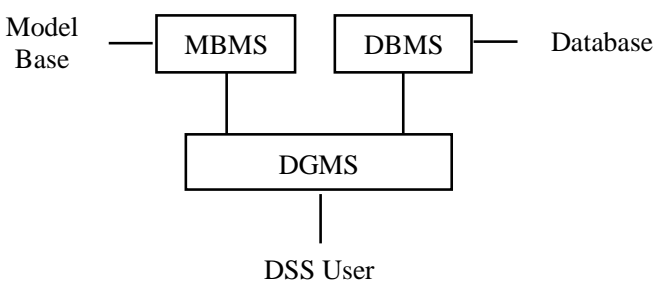

Gambar 1. Komponen SPK [5]:

Metode yang akan digunakan untuk menyelesaikan masalah tersebut adalah metode Analythical Hierarchy Process (AHP), metode ini mampu menyeleksi untuk menentukan alternatif yang terbaik berdasarkan kriteri-kriteria yang sudah ditentukan [6]. Metode Analitycal Hierarchy Process (AHP) dikembangkan oleh Thomas L. Saaty pada tahun 1970an, seorang ahli matematika [7]. AHP merupakan metode yang digunakan dalam penelitian kuantitatif untuk merangking berbagai alternatif dalam memilih satu atau beberapa nilai tertinggi berdasarkan kriteria yang ditentukan. Metode AHP ini diharapkan dapat melakukan perbandingan dari beberapa pilihan dengan kriteria-kriteria yang telah ditentukan [8][9]. 
Berdasarkan penelitian sebelumnya sebagai referensi dalam penelitian ini, yaitu Perancangan sistem pendukung keputusan untuk pemilihan lokasi dalam perluasan usaha kafe menggunakan Analitycal Hierarchy Process, tujuan dari penelitian ini untuk mengetahui bagaimana metode AHP mampu memberikan solusi pemecahan masalah dalam pemilihan lokasi dalam perluasan usaha bisnis café, serta bagaimana membangun sebuah aplikasi sistem pendukung keputusan metode AHP [10].

Penelitian lainnya yaitu Sistem penunjang keputusan dengan menggunakan metode AHP dalam seleksi produk, penelitian tersebut bertujuan membantu mini market untuk melihat produk mana yang diminati. Kemudian keuntungan yang didapat adalah membantu Manajer Mini Market untuk menyediakan produk yang diminati agar tidak terjadi penumpukan produk yang mengakibatkan kerugian [11].

Penelitian sebelumnya adalah Penerapan Metode AHP Untuk Membantu Siswa Memilih Jurusan Yang Tepat Di SMK, penelitian ini bertujuan untuk dapat membantu sekolah khususnya untuk menentukan beberapa persoalan mengenai pemilihan jurusan. Karena metode AHP yaitu suatu metode yang input utamannya adalah persepsi manusia [12].

\section{METODE PENELITIAN}

Metode penelitian yang digunakan dalam sistem pendukung keputusan pemilihan mobil bekas dapat dilihat dalam kerangka penelitian dibawah ini:

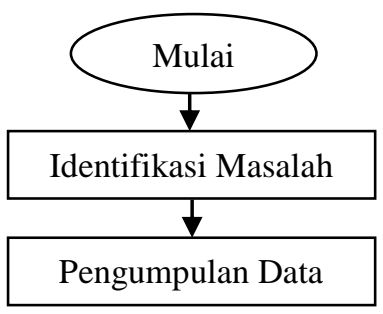

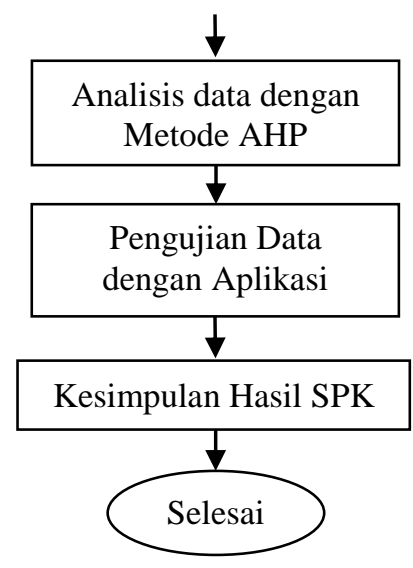

Gambar 1. Kerangka Penelitian

Berdasarkan dari gambar kerangka penelitian diatas dapat diuraikan sebagai berikut:

a. Identifikasi masalah

Merupakan tahap awal yang dilakukan seperti mendefinisikan masalah, menetunkan tujuan, kriteria, sub kriteria dan solusi.

b. Pengumpulan data

Proses pengumpulan data dilakukan dengan mengunjungi dan wawancara langsung pada pemilik Showroom Ragasa Motor yang berada di kota padang.

c. Analisis dengan metode AHP

Setelah tahap pertama dan kedua dilakukan, tahap selanjutnya adalah menganalis data menggunakan metode AHP, metode ini melakukan proses perbandingan kriteria berdasarkan tingkat kepentingan secara hirarki.

d. Pengujian data dengan aplikasi

Setelah melakukan analisis data, maka dilanjutkan dengan proses pengujian data, proses ini dilakukan untuk mengetahui ke akuratan dalam mengolah data yang sudah dilakukan dengan cara manual dan aplikasi yang sudah diuji dapat digunakan oleh user untuk memudahkan dalam pemilihan mobil bekas. Aplikasi SPK ini yang dibaungun menggunakan bahasa 
pemrograman PHP: Hypertext Prepocessor.

e. Kesimpulan

Langkah terakhir adalah menarik kesimpulan terhadap data yang sudah diolah baik secara manual maupun secara komputerisasi. Hasil kesimpulan berupa perangkingan data dari yang tertinggi sampai yang terendah.

\section{HASIL DAN PEMBAHASAN}

Sistem pendukung keputusan pemilihan mobil bekas dalam penelitian ini dengan metode Analythical Hierarchy Process (AHP), menggunakan 5 kriteria penilaian yaitu : Konsumsi BBM (C1), Transmisi (C2), CC (C3), Harga (C4), Tahun (C5). Berdasarkan identifikasi masalah yang telah dilakukan, maka dapat digambarkan struktur hirarki dalam proses metode AHP sebagai berikut:

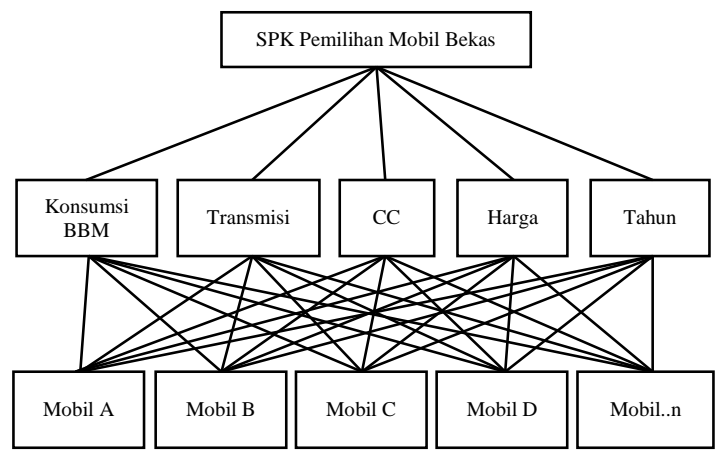

Gambar 2. Struktur Hirarki AHP

Dalam menyelesaikan masalah tentang pemilihan mobil bekas pada kasus ini menggunakan metode AHP, ada 2 proses tahapan yang dilalui yaitu menentukan nilai prioritas versi kriteria dan menentukan nilai prioritas versi subkriteria. Tahap-tahapan penyelesaian kasus dengan metode AHP, sebagai berikut:

A. Menentukan nilai prioritas kriteria Dalam langkah pertama ini, tahapan yang dilalui adalah:
1. Membuat matriks perbandingan berpasangan

Menentukan matriks perbandingan berpasangan menggunakan nilai pada tabel skala perbandingan berpasangan dibawah ini [13]:

Tabel 1. Skala penilaian perbandingan berpasangan

\begin{tabular}{|c|c|c|}
\hline $\begin{array}{c}\text { Intensitas } \\
\text { Kepentingan }\end{array}$ & Keterangan & Penjelasan \\
\hline 1 & $\begin{array}{l}\text { Kedua elemen sama } \\
\text { pentingnya. }\end{array}$ & $\begin{array}{l}\text { Dua elemen } \\
\text { mempunyai } \\
\text { pengaruh yang sama } \\
\text { besar terhadap } \\
\text { tujuan }\end{array}$ \\
\hline 3 & $\begin{array}{l}\text { Elemen yang satu } \\
\text { sedikit lebih penting } \\
\text { dari pada elemen yang } \\
\text { lainnya. }\end{array}$ & $\begin{array}{lr}\text { Pengalaman } & \text { dan } \\
\text { penilaian sedikit } & \text { satu } \\
\text { menyokong } & \text { elemen } \\
\text { dibandingkan } & \\
\text { elemen yang lain. }\end{array}$ \\
\hline 5 & $\begin{array}{l}\text { Elemen yang satu } \\
\text { sedikit lebih penting }\end{array}$ & $\begin{array}{lr}\text { Pengalaman } & \text { dan } \\
\text { penilaian } & \text { yang } \\
\text { sangat } & \text { kuat } \\
\text { menyokong } & \text { satu } \\
\text { elemen } & \\
\text { dibandingkan } & \\
\text { elemen yang lain } \\
\end{array}$ \\
\hline 7 & $\begin{array}{l}\text { Satu elemen jelas lebih } \\
\text { mutlak penting dari } \\
\text { pada elemen lainnya }\end{array}$ & $\begin{array}{l}\text { Satu elemen yang } \\
\text { sangat kuat } \\
\text { disokong dan } \\
\text { dominan terlihat } \\
\text { dalam praktek Bukti } \\
\text { yang mendukung }\end{array}$ \\
\hline 9 & $\begin{array}{l}\text { Satu elemen mutlak } \\
\text { penting dari pada } \\
\text { elemen yang lainnya }\end{array}$ & $\begin{array}{l}\text { Elemen yang satu } \\
\text { terhadap elemen lain } \\
\text { memiliki tingkat } \\
\text { penegasan tertinggi } \\
\text { yang mungkin } \\
\text { menguatkan }\end{array}$ \\
\hline $2,4,6,8$ & $\begin{array}{l}\text { Nilai-nilai antara dua } \\
\text { nilai pertimbangan } \\
\text { yang berdekatan }\end{array}$ & $\begin{array}{l}\text { Nilai ini diberikan } \\
\text { bila ada dua } \\
\text { kompromi diantara } \\
\text { dua pilihan }\end{array}$ \\
\hline
\end{tabular}

Setiap kriteria dibandingkan dengan kriteria yang lain secara berpasangan berdasarkan pada nilai pada tabel diatas maka hasil perbandingan akan ditempatkan pada rating baris dan kolom yang sesuai dengan criteria perbandingan berpasangan tersebut, seperti pada tabel dibawah ini.

Tabel 2. Matriks Perbandingan Berpasangan

\begin{tabular}{|c|c|c|c|c|c|}
\hline & C1 & C2 & C3 & C4 & C5 \\
\hline A1 & 1 & 3 & 5 & 5 & 7 \\
\hline A2 & 0,33 & 1 & 2 & 3 & 5 \\
\hline A3 & 0,2 & 0,5 & 1 & 3 & 5 \\
\hline
\end{tabular}




\begin{tabular}{|c|c|c|c|c|c|}
\hline A4 & 0,2 & 0,33 & 0,33 & 1 & 5 \\
\hline A5 & 0,14 & 0,2 & 0,2 & 0,2 & 1 \\
\hline JML & $\mathbf{1 , 8 7}$ & $\mathbf{5 , 0 3}$ & $\mathbf{8 , 5 3}$ & $\mathbf{1 2 , 2}$ & $\mathbf{2 3}$ \\
\hline
\end{tabular}

2. Matriks bobot nilai antar kriteria dan prioritas

Menentukan nilai matriks ini berdasarkan nilai dari tabel 1 dengan cara membagi setiap rating alternatif.

Tabel 3. Matriks bobot nilai antar kriteria dan prioritas.

\begin{tabular}{|c|c|c|c|c|c|c|}
\hline C1 & C2 & C3 & C4 & C5 & Jml & P \\
\hline 0,53 & 0,60 & 0,59 & 0,41 & 0,30 & 2,43 & 0,486 \\
\hline 0,18 & 0,20 & 0,23 & 0,25 & 0,22 & 1,08 & 0,216 \\
\hline 0,11 & 0,10 & 0,12 & 0,25 & 0,22 & 0,8 & 0,16 \\
\hline 0,11 & 0,07 & 0,04 & 0,08 & 0,22 & 0,52 & 0,104 \\
\hline 0,07 & 0,04 & 0.02 & 0,02 & 0,04 & 0,19 & 0,038 \\
\hline
\end{tabular}

3. Matriks Penjumlahan Setiap Baris

Hasil dari matriks penjumlahan setiap baris didapatkan dari hasil perkalian nilai prioritas dengan nilai matriks perbandingan berpasangan.

Tabel 4. Matriks penjumlahan setiap baris

\begin{tabular}{|c|c|c|c|c|c|}
\hline C1 & C2 & C3 & C4 & C5 & JML \\
\hline 0,486 & 0,648 & 0,8 & 0,52 & 0,266 & 2,72 \\
\hline 0,160 & 0,216 & 0,32 & 0,312 & 0,19 & 1,198 \\
\hline 0,097 & 0,108 & 0,16 & 0,312 & 0,19 & 0,867 \\
\hline 0,097 & 0,071 & 0,053 & 0,104 & 0,19 & 0,515 \\
\hline 0,068 & 0,043 & 0,032 & 0,021 & 0,038 & 0,202 \\
\hline
\end{tabular}

\section{Nilai Rasio Konsistensi Kriteria}

Berdasarkan hasil dari pembagian dan penjumlahan dari kolom jumlah dan kolom prioritas dengan nilai 26,83 maka dapat ditentukan:

$\lambda$ maks $=\frac{26,83}{5}=5,366$

$C I=\frac{5,366-5}{5-1}=\frac{0,366}{4}=0,0915$

$C R=\frac{0,0915}{1,12}=0,082$

Hasil dari Consistency Ratio (CR) adalah 0,082 maka angka perbandingan berpasangan yang digunakan adalah konsisten, karena nilai batas (Treshold) adalah $\leq 0,1$.
5. Menentukan nilai hasil dengan data Berdasarkan dari langkah ke 4 diatas dalam menentukan kekonsistenan data, maka langkah yang terakhir adalah menentukan nilai yang tertinggi dalam mengambil keputusan.

Tabel 5. Data Penilaian Mobil Bekas

\begin{tabular}{|c|c|c|c|c|c|}
\hline Prioritas & $\mathrm{C} 1$ & $\mathrm{C} 2$ & $\mathrm{C} 3$ & $\mathrm{C} 4$ & $\mathrm{C} 5$ \\
\cline { 2 - 6 } Kriteria & $\mathbf{0 , 4 8 6}$ & $\mathbf{0 , 2 1 6}$ & $\mathbf{0 , 1 6}$ & $\mathbf{0 , 1 0 4}$ & $\mathbf{0 , 0 3 8}$ \\
\hline A1 & 1 & 3 & 1 & 3 & 3 \\
\hline A2 & 3 & 2 & 3 & 1 & 2 \\
\hline A3 & 2 & 3 & 2 & 1 & 3 \\
\hline A4 & 3 & 2 & 1 & 2 & 3 \\
\hline A5 & 2 & 3 & 3 & 3 & 2 \\
\hline
\end{tabular}

Nilai data pada Tabel 5 didapatkan setelah dilakukan proses konversi data, dan dilakukan Proses perkalian nilai alternatif dengan nilai prioritas, dengan hasil pada tabel dibawah ini.

Tabel 6. Menentukan nilai tertinggi.

\begin{tabular}{|c|c|c|c|c|c|c|}
\hline Prioritas & $\mathrm{C} 1$ & $\mathrm{C} 2$ & C3 & $\mathrm{C} 4$ & C5 & \multirow{2}{*}{ Jumlah } \\
\hline Kriteria & \begin{tabular}{|l|}
0,486 \\
\end{tabular} & 0,216 & 0,16 & 0,104 & 0,038 & \\
\hline $\mathrm{A} 1$ & 0,486 & 0,648 & 0,16 & 0,312 & 0,114 & 1,72 \\
\hline A2 & 1,458 & 0,432 & 0,48 & 0,104 & 0,076 & 2,55 \\
\hline A3 & 0,972 & 0,648 & 0,32 & 0,104 & 0,114 & 2,158 \\
\hline A4 & 1,458 & 0,432 & 0,16 & 0,208 & 0,114 & 2,372 \\
\hline A5 & 0,972 & 0,648 & 0,48 & 0,312 & 0,076 & 2,488 \\
\hline
\end{tabular}

Berdasarkan hasil perhitungan tabel hasil maka nilai total yang tertinggi terpilih sebagai Mobil bekas terbaik yaitu Alternatif ke-2 dengan nilai 2,55

B. Pengujian sistem pendukung keputusan dengan metode AHP.

Untuk memudahkan user dalam menggunkan sistem SPK ini, maka diterapkan ke dalam bentuk aplikasi menggunakan bahasa pemrograman PHP dan database MySQL. Tampilan aplikasi SPK adalah sebagai berikut:

1. Form Pilih Kriteria

Tampilan form ini, kita dapat memilih kriteria penilaian yang akan kita gunakan. 


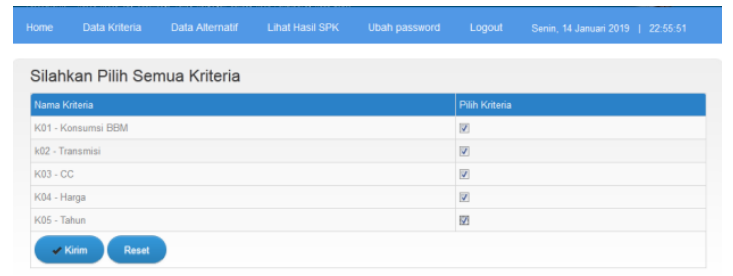

Gambar 3. Tampilan Form Pilih Kriteria

\section{Form Alternatif}

Pada form pilih alternatif ini, kita dapat memilih jenis mobil bekas yang akan kita nilai yang akan dipilih salah satu yang terbaik nantinya.

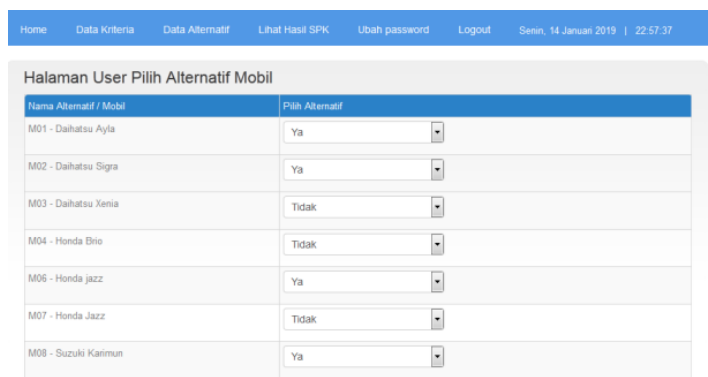

Gambar 4. Tampilan Form Pilih Alternatif

3. Form data penilaian perbandingan berpasangan

Setiap criteria akan dinilai secara berpasangan untuk menentukan nilai Consistency Ratio (CR).

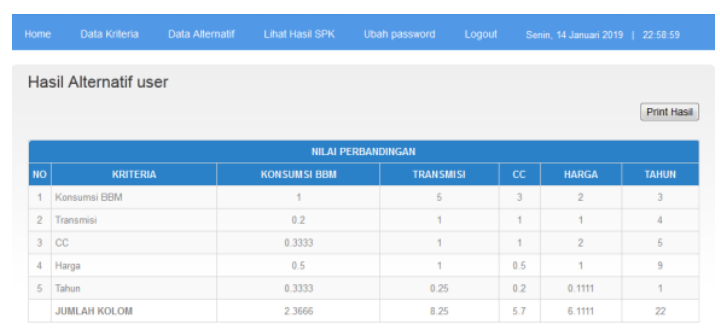

Gambar 5. penilaian kriteria berpasangan

4. Form nilai hasil dan perangkingan Pada tampilan form dibawah ini, user dapat melihat hasil akhir untuk mengambil keputusan dengan merangking mulai dari nilai yang tertinggi sampai dengan dengan nilai yang terendah, nilai yang tertinggi ditetapkap sebagai alternatif yang terbaik.

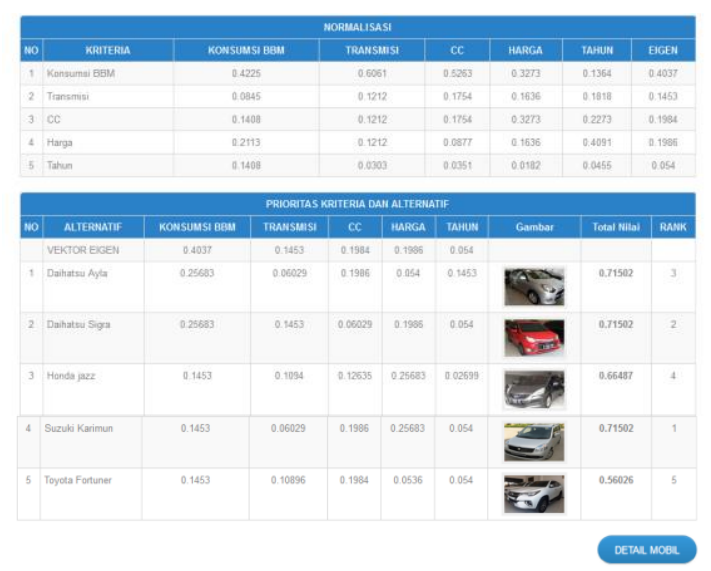

Gambar 6. Form nilai hasil perangkingan

\section{SIMPULAN}

berdasarkan pembahasan dalam penelitian ini, maka dapat ambil kesimpulan sebagai berikut:

a. Setelah membangun sistem pendukung keputusan menggunakan metode Analythical Hierarchy Process (AHP) mampu mengambil keputusan dalam membantu user pemilihan mobil bekas dengan cepat dan akurat.

b. Setelah membangun aplikasi SPK menggunakan bahasa pemrograman PHP, dapat mengolah data dan dengan cepat dan memudahkan user dalam mengambil keputusan

c. Setelah menggunakan database MySQL, data sistem pengambilan keputusan dapat disimpan dengan baik dan aman.

\section{UCAPAN TERIMAKASIH}

Kami ucapan terima kasih kepada pihak yang telah memberikan dukungan terhadap penelitian ini.

\section{DAFTAR PUSTAKA}

[1] A. Dirgantara, S. Herdyansyah, and R. Rasenda, "KLASIFIKASI 


\begin{tabular}{|c|c|}
\hline $\begin{array}{l}\text { PENERIMAAN MOBIL } \\
\text { BERDASARKAN }\end{array}$ & $\begin{array}{r}\mathrm{B} \\
\mathrm{ME}\end{array}$ \\
\hline NEURAL NETWORK," & , J. \\
\hline $\begin{array}{l}\text { Inform., } 2020, \\
\text { 10.34288/jri.v2i1.119. }\end{array}$ & \\
\hline
\end{tabular}

[2] Dicky Nofriansyah dan Sarjon Defit, "Multi Criteria Decision Making (MCDM) pada Sistem Pendukung Keputusan," in Journal of Chemical Information and Modeling, 2017.

[3] M. Marbun and B. Sinaga, Buku Ajar Sistem Pendukung Keputusan Penilaian Hasil Belajar Metode Topsis. 2019.

[4] D. Guswandi and M. Yanto, "Sistem Pendukung Keputusan Pemilihan Calon Wali Nagari Menggunakan Metode TOPSIS," KOMTEKINFO, 2021, doi: 10.35134/komtekinfo.v8i1.1611.

[5] T. Limbong et al., Sistem Pendukung Keputusan Metode \& Implementasi. 2020.

[6] E. Rosiska, "Penerapan Metode Analitycal Hierarchy Process (AHP) dalam Menentukan Mitra Usaha Berprestasi," J. RESTI (Rekayasa Sist. dan Teknol. Informasi), 2018, doi: 10.29207/resti.v2i2.419.

[7] A. Sasongko, I. F. Astuti, and S. Maharani, "Pemilihan Karyawan Baru Dengan Metode AHP (Analytic Hierarchy Process)," Inform. Mulawarman J. Ilm. Ilmu Komput., 2017, doi: 10.30872/jim.v12i2.650.

[8] S. Utomo and T. Mardiono, "Sistem Pendukung Keputusan Pemilihan Rumah Pada Perumahan Menggunakan Metode Analytical Hierarchy Process (Studi Kasus : Kec. Ngamprah Kab. Bandung Barat)," J. Teknol. Inf. dan Komun. |ISSN, 2018.
[9] F. F. H. Hadi and G. Gushelmi, "SISTEM PENGAMBILAN KEPUTUSAN PEMILIHAN SISWA YANG BERHAK MENDAPATKAN BEASISWA MISKIN DENGAN METODE ANALYTICAL HIERARCHY PROCESS (AHP)," $J$. Teknol. Dan Sist. Inf. Bisnis, 2021, doi: 10.47233/jteksis.v3i1.173.

[10] W. Priatna and Suryadi, "Perancangan Sistem Pendukung Keputusan Untuk Pemilihan Lokasi Dalam Perluasan Usaha Kafe menggunakan Analytical Hierarchy Process," J. RESTI (Rekayasa Sist. dan Teknol. Informasi), 2019, doi: 10.29207/resti.v3i3.1263.

[11]M. Yanto, "SISTEM PENUNJANG KEPUTUSAN DENGAN MENGGUNAKAN METODE AHP DALAM SELEKSI PRODUK," $J$. Teknol. Dan Sist. Inf. Bisnis, 2021, doi: 10.47233/jteksis.v3i1.161.

[12]F. Frieyadie and S. M. Ramadhan, "Penerapan Metode AHP Untuk Membantu Siswa Memilih Jurusan Yang Tepat Di SMK," J. RESTI (Rekayasa Sist. dan Teknol. Informasi), 2018, doi: 10.29207/resti.v2i3.396.

[13] T. Rahayu, E. Krisnanik, and B. Hananto, "Metode Analytical Hierarchy Process Dalam Menentukan Pemilihan Desa Terbaik," J. RESTI (Rekayasa Sist. dan Teknol. Informasi), 2019, doi: 10.29207/resti.v3i1.769. 